\title{
COVID-19 Vaccine Hesitancy and Acceptance among Medical Students: An Online Cross-sectional Study in Iraq
}

\author{
Batool Mutar Mahdi*(D) \\ Department of Microbiology, Al-Kindy College of Medicine, University of Baghdad, Baghdad, Iraq
}

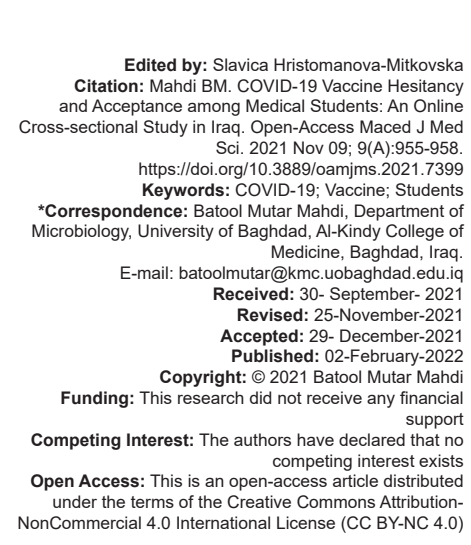

Introduction

Coronavirus disease 19 (COVID-19) caused by rapidly spread coronavirus all over the world resulted in public health crisis and global threat [1]. This pandemic has created an urgent need for vaccine development in spite of control measures against COVID-19 and massive vaccination has emerged as a solution preventive measure to control this disease [2]. There are many types of vaccines with different potency, and duration of efficacy according to the antigen design, adjuvant molecules used, route of vaccine delivery, and immunization method [3]. Thus, arrival of COVID-19 vaccines was a real end of health, industries, tourism, and economic suffering but the rolling out of vaccination is actually challenging in some countries in the world [4]. People who had a priority for vaccination are health care workers, doctors, nurses, and medical students because they are at a high risk for acquiring viral infection or transmitting the disease to other persons [5]. Thus, protecting health care workers and people against COVID-19 by vaccine are important which is a viable future option and end of pandemic. On the other hand, vaccine hesitancy or refusal remains a global challenge and worldwide decline in public trust in immunization due to political views of people that play an important role in their attitude [6], [7]. An online survey in a French sample aged 18 years and older showed that $26 \%$ of respondents demonstrated that they would not use it and $37 \%$ of low-income people were more reluctant to vaccine [8]. On the other hand, stakeholders such as government and the World Health Organization should be effectively build the positive impacts of COVID-19 vaccine [9].

The aim of this study is to assess vaccine hesitancy, acceptance, and refusal of medical students at Al-Kindy College of Medicine to a new COVID-19 vaccine. Information obtained will help recognize possible concerns to be tackled to ensure adequate uptake among medical students and enable development of educational plans to teach skills to provide vaccine recommendations and advice vaccine hesitant people.

\section{Materials and Methods}

The cross-sectional study was conducted with medical students at University of Baghdad, Al-Kindy College of Medicine in Baghdad, Iraq, during 2021. Out 
of total number of students, only a suitable sample of 810 students was selected and was agreed to participate in the anonymous online survey. The data were collected using online multi-item questionnaire was created based on reviewing past research relating to vaccinations and a comprehensive literature review [10], [11], [12]. The questionnaire was distributed to the medical students through the use of the Google Forms tool. The survey was sent to students through social media including: E-mail, Facebook, Telegram, and Instagram groups of general medical students. The survey assessed personal data such as age, sex, academic year and residence, current knowledge about vaccine, general attitudes, perception of vaccines, likelihood of getting vaccine (vaccine hesitancy), vaccinated or not, first or second dose, side effect of vaccine, and infected after COVID-19 vaccine.

The study protocol was reviewed by the Scientific and Ethical Committee of Al-Kindy Medical College without funding. Each participant was anonymized and numbered with a code to guarantee their data confidentiality.

\section{Statistical analysis}

The data were analyzed using SPSS version 25. Descriptive statistics including frequencies and percentages. Independent Pearson's Chi-square test was used to identify significant differences between pre-clinical and clinical students who would accept and refuse the COVID-19 vaccine. $p<0.05$ was considered statistically significant.

Logistic regression was used to identify predictors of COVID-19 vaccine uptake.

\section{Results}

A total of 810 adults' medical students participated in this study. The majority of the study participants were female $(488,60.2 \%)$ while males were 322, 39.8\% (Table 1). Vaccine concept hesitancy among males was $65.21 \%$ and rest were vaccinated $(34.78 \%)(\mathrm{OR}=0.13)(95 \% \mathrm{Cl}=0.096-0.177)$ $(p=0.0001)$. Same hesitancy from COVID-19 vaccine was same with females $(66.80 \%)$. Most of them their age ranged from 16 to 19 years $(42.59 \%)$ and vaccine idea acceptance in this group was $32.47 \%$. Students in the pre-clinical stage constitute $76.66 \%$ of the total participants with about same percent of vaccine refusal $(60.06 \%)$. Majority of the students were lived in Baghdad province $(79.87 \%)$ with high frequency of vaccine idea refusal $(76.50 \%)(O R=0.09)(p=0.0001)$. Regarding the questions on their health and disease status, small percent of them had previous diseases $(11.9 \%)$ (Table 2 ) and $3.7 \%$ of them had chronic diseases with treatment. Concerning vaccine thought acceptance in this group of students was $12.5 \%$ and the rest $(87.5 \%)$ were reluctant vaccination $(O R=0.02)$ (95\% Cl $=0.008-0.048)(p=0.0001)$.

COVID-19 status of medical students was $42.6 \%$ had COVID-19 and $60.86 \%$ accept vaccine thought $(O R=2.41)(p=0.0001)$. About $52.17 \%$ their disease were diagnosed by signs and symptoms and $87.22 \%$ of them agree to have vaccine and $44.92 \%$ were diagnosed by PCR test to nasal or pharyngeal swab with vaccine believe rate were $79.35 \%$ and the rest were diagnosed by CT scan of lung $(2.89 \%)$ (Table 2).

Students that had a vaccine whether Pfizer, AstraZeneca, or Sinopharm constitute $13.3 \%$ and $86.11 \%$ of them had two doses of vaccines. Most of them had side effects $(84.25 \%)$ such as pain at the site of injection, fever, fatigue, and axillary lymphadenitis that lasts for 1-2 weeks (80.55\%). Majority of them were not used treatment (74.07\%). About $13.88 \%$ of them were reinfected with COVID-19 again.

\section{Discussion}

The COVID-19 pandemic is one of the first causes of hospitalization and death worldwide and many people should be vaccinated to prevent bad prognosis of this disease, especially old age, health care workers, and patients with chronic disease after approve of these vaccines by Centers for Disease Control and Preventions and FDA. Nearly one-quarter of the medical students in this study were hesitated to be vaccinated in this study despite perception and knowledge of increased risk of exposure to this virus. This study was in difference with other study that demonstrated that vaccine is a central role of protection of COVID-19 infections and considered as a key protective behavior [13]. The main causes regarding vaccine refusal by medical students were serious side effects after vaccination, lack of trust in those vaccines due to information get it from public health and social media, and afraid from reinfection with this virus [14]. Others are willing to get vaccine after acceptability should be checked after the development of vaccine and became worldwide [15]. One of the important groups that should be confident and sure about vaccine safety and effectiveness against viral infection is medical health care, doctors, and medical students [16]. The reasons for that were physicians and medical students play an important task in influencing the decisions and their recommendations about vaccine intake among general populations [17]. Other studies have mentioned that vaccinated medical students have a positive attitude and idea about vaccine 
Table 1: Sociodemographic characters of the participants

\begin{tabular}{|c|c|c|c|c|c|}
\hline Survey item & $\begin{array}{l}\text { All students } \\
\text { No. }=810 \\
\text { No. }(\%)\end{array}$ & $\begin{array}{l}\text { Vaccine idea acceptance } \\
\text { No. }=108 \\
\text { No. }(\%)\end{array}$ & $\begin{array}{l}\text { Vaccine idea hesitancy } \\
\text { No. }=702 \\
\text { No. }(\%)\end{array}$ & $\begin{array}{l}\text { Odds ratio } \\
95 \% \mathrm{Cl}\end{array}$ & $p$ value \\
\hline Male gender & $322(39.8)$ & $112(34.78)$ & $210(65.21)$ & $\begin{array}{l}0.13 \\
0.096-0.177\end{array}$ & 0.0001 \\
\hline Female gender & $488(60.2)$ & $162(33.19)$ & $326(66.80)$ & $\begin{array}{l}0.24 \\
0.189-0.322\end{array}$ & 0.0001 \\
\hline Age $16-19$ years & $465(57.4)$ & $151(32.47)$ & $314(67.52)$ & $\begin{array}{l}0.231 \\
0.175-0.304\end{array}$ & 0.0001 \\
\hline Age $20-25$ years & $345(42.59)$ & $110(31.88)$ & $235(68.11)$ & $\begin{array}{l}0.21 \\
0.159-0.301\end{array}$ & 0.0001 \\
\hline 1-3 stage pre-clinical & $621(76.66)$ & $248(39.93)$ & $373(60.06)$ & $\begin{array}{l}0.44 \\
0.352-0.554\end{array}$ & 0.0001 \\
\hline 4-6 stage clinical & $189(23.33)$ & $72(38.09)$ & 117 (61.90) & $\begin{array}{l}0.37 \\
0.250-0.573\end{array}$ & 0.0001 \\
\hline Province Baghdad & $647(79.87)$ & $152(23.49)$ & $495(76.50)$ & $\begin{array}{l}0.09 \\
0.072-0.121\end{array}$ & 0.0001 \\
\hline Other province & $163(20.12)$ & $77(47.23)$ & $86(52.76)$ & $\begin{array}{l}0.81 \\
0.526-1.253\end{array}$ & 0.347 \\
\hline
\end{tabular}

Table 2: Survey responses among medical students (No. $=810$ )

\begin{tabular}{|c|c|c|c|c|c|}
\hline \multirow[t]{5}{*}{ Survey item } & \multicolumn{5}{|c|}{ Health and disease status of the participants } \\
\hline & \multicolumn{5}{|c|}{ Participants that responded affirmatively (yes) } \\
\hline & All students & Vaccine idea acceptance & Vaccine idea hesitancy & Odds ratio & $\mathrm{p}$ value \\
\hline & No. $=810$ & No. $=108$ & No. $=702$ & $95 \% \mathrm{Cl}$ & \\
\hline & No. $(\%)$ & No. $(\%)$ & No. $(\%)$ & & \\
\hline Have a previous disease that interfere with vaccine & $96(11.9)$ & $12(12.5)$ & $84(87.5)$ & $\begin{array}{l}0.02 \\
0.008-0.048\end{array}$ & 0.0001 \\
\hline Have a chronic diseases & $30(3.7)$ & $5(16.66)$ & $25(83.33)$ & $\begin{array}{l}0.04 \\
0.010-0.155\end{array}$ & 0.0001 \\
\hline Have allergy from vaccines or drugs & $80(9.9)$ & $19(23.75)$ & $61(76.25)$ & $\begin{array}{l}0.09 \\
0.046-0.201\end{array}$ & 0.0001 \\
\hline Have a drugs for chronic diseases & $30(3.7)$ & $5(16.66)$ & $25(83.33)$ & $\begin{array}{l}0.04 \\
0.010-0.155\end{array}$ & 0.0001 \\
\hline \multicolumn{6}{|l|}{ COVID-19 status of medical students. } \\
\hline $\begin{array}{l}\text { Have COVID-19 } \\
\text { previously }\end{array}$ & $345(42.6)$ & $210(60.86)$ & $135(39.13)$ & $\begin{array}{l}2.41 \\
1.782-3.285\end{array}$ & 0.0001 \\
\hline $\begin{array}{l}\text { Confirm COVID-19 infection by signs and } \\
\text { symptoms }\end{array}$ & $180(52.17)$ & $157(87.22)$ & $23(12.77)$ & $\begin{array}{l}46.59 \\
25.094-86.519\end{array}$ & 0.0001 \\
\hline PCR test positive & $155(44.92)$ & $123(79.35)$ & $32(20.64)$ & $\begin{array}{l}14.77 \\
8.523-25.609\end{array}$ & 0.0001 \\
\hline CT lung positive & $10(2.89)$ & $8(80)$ & $2(20)$ & $\begin{array}{l}16 \\
1.788-143.156\end{array}$ & 0.013 \\
\hline \multicolumn{6}{|l|}{ COVID-19 vaccine status of medical students. } \\
\hline COVID-19 & $702(86.7)$ & $100(14.24)$ & $602(85.75)$ & 0.0008 & 0.0001 \\
\hline $\begin{array}{l}\text { Hesitancy } \\
\text { COVID-19 acceptance }\end{array}$ & $108(13.3)$ & $108(100)$ & $0(0)$ & $0.000-0.012$ & \\
\hline Two doses of vaccine & $93(86.11)$ & & & & \\
\hline Side effect of vaccine - mild pain, fever & $108(84.25)$ & & & & \\
\hline Duration of these symptoms for $1-2$ weeks & $87(80.55)$ & & & & \\
\hline Not used drugs for these symptoms & $80(74.07)$ & & & & \\
\hline Infected with COVID-19 after vaccines & $15(13.88)$ & & & & \\
\hline
\end{tabular}

and encourage vaccine uptake [11]. Other study in Pakistan showed that students enrolled in different medical universities of Pakistan were aware of the COVID-19 [18]. Most of them were afraid from different COVID-19 symptoms [19]. Thus, this study evaluates and assesses vaccine hesitancy and acceptance among sample of medical students in Iraq.

\section{Conclusions}

This study evaluated and shed light on vaccine hesitancy among sample of Iraqi medical students toward COVID-19 vaccination program and considered medical students as leaders and guides in the health system for increased planning and education of the population for COVID-19 vaccine acceptability.

\section{Limitations}

This study includes single medical college that may impact generalizability. There was low access rate and it was difficult to follow the patients after infection or after vaccination.

\section{References}

1. Behera BC, Mishra RR, Thatoi H. Recent biotechnological tools for diagnosis of corona virus disease: A review. Biotechnol Prog. 2021;37(1):e3078. http://doi.org/10.1002/btpr.3078 PMid:32902193

2. Kumar VM, Pandi-Perumal SR, Trakht I, Thyagarajan SP. Strategy for COVID-19 vaccination in India: The country with the second highest population and number of cases. NPJ Vaccines. 2021;6(1):60

3. Park KS, Sun X, Aikins ME, Moon JJ. Non-viral COVID-19 vaccine delivery systems. Adv Drug Deliv Rev. 2021;169:137-51. 
http://doi.org/10.1016/j.addr.2020.12.008 PMid:33340620

4. World Health Organization. Ten Threats to Global Health in 2019. Geneva: World Health Organization; 2019. Available from: https://www.who.int/news-room/spotlight/ten-threats-toglobal-health-in-2019 [Last accessed on 2021 Mar 31].

5. Yin Q, Sun Z, Liu T, Ni X, Deng X, Jia Y, et al. Posttraumatic stress symptoms of health care workers during the corona virus disease 2019. Clin Psychol Psychother. 2020;27(3):384-95. http://doi.org/10.1002/cpp.2477

PMid:32415733

6. Kwok KO, Li KK, Wei WI, Tang A, Wong SY, Lee SS. Editor's Choice: Influenza vaccine uptake, COVID-19 vaccination intention and vaccine hesitancy among nurses: A survey. Int J Nurs Stud. 2021;114:103854. http://doi.org/10.1016/j. ijnurstu.2020.103854

PMid:33326864

7. COCONEL Group. A future vaccination campaign against COVID-19 at risk of vaccine hesitancy and politicisation. Lancet Infect Dis. 2020;20(7):769-70. http://doi.org/10.1016/ S1473-3099(20)30426-6

PMid:32445713

8. de Noordhout CM, Devleesschauwer B, Salomon JA, Turner H Cassini A, Colzani E, et al. Disability weights for infectious diseases in four European countries: Comparison between countries and across respondent characteristics. Eur J Public Health. 2018;28:124-33. http://doi.org/10.1093/eurpub/ckx090 PMid:29020343

9. Ali I. Impact of COVID-19 on vaccination programs: Adverse or positive? Hum Vaccin Immunother. 2020;16(11):2594-600. http://doi.org/10.1080/21645515.2020.1787065 PMid:32961081

10. Larson HJ, Jarrett C, Schulz WS, Chaudhuri M, Zhou Y, Dube E, et al. Measuring vaccine hesitancy: The development of a survey tool. Vaccine. 2015;33(34):4165-75. http://doi.org/10.1016/j. vaccine.2015.04.037 PMid:25896384

11. Kernéis $\mathrm{S}$, Jacquet $\mathrm{C}$, Bannay $\mathrm{A}$, May $\mathrm{T}$, Launay $\mathrm{O}$, Verger $\mathrm{P}$ et al. Vaccine education of medical students: A nationwide cross-sectional survey. Am J Prev Med. 2017;53(3):e97-104. http://doi.org/10.1016/j.amepre.2017.01.014

PMid:28237636

12. Afonso NM, Kavanagh MJ, Swanberg SM, Schulte JM, Wunderlich T, Lucia VC. Will they lead by example? Assessment of vaccination rates and attitudes to human papilloma virus in millennial medical students. BMC Public Health. 2017;17(1):35. http://doi.org/10.1186/s12889-016-3969-x

PMid:28056900

13. Betsch C, Wicker S. E-health use, vaccination knowledge and perception of own risk: Drivers of vaccination uptake in medical students. Vaccine. 2012;30(6):1143-8. http://doi.org/10.1016/j. vaccine.2011.12.021 PMid:22192850

14. Dror AA, Eisenbach N, Taiber S, Morozov NG, Mizrachi M, Zigron A, et al. Vaccine hesitancy: The next challenge in the fight against COVID-19. Eur J Epidemiol. 2020;35(8):775-9. http://doi.org/10.1007/s10654-020-00671-y PMid:32785815

15. Reiter PL, Pennell ML, Katz ML. Acceptability of a COVID-19 vaccine among adults in the United States: How many people would get vaccinated? Vaccine. 2020;38(42):6500-7. http://doi. org/10.1016/j.vaccine.2020.08.043

PMid:32863069

16. DeRoo SS, Pudalov NJ, Fu LY. Planning for a COVID-19 vaccination program. JAMA. 2020;323(24):2458-9. http://doi. org/10.1001/jama.2020.8711 PMid:32421155

17. Edwards KM, Hackell JM. Committee on infectious diseases, the committee on practice and ambulatory medicine. Countering vaccine hesitancy. Pediatrics. 2016;138(3):2016-146. http://doi. org/10.1542/peds.2016-2146 PMid:27573088

18. Ali A, Haq $N$, Naqi $S$, Hussain $A$, Rafique $M$, Ismail $M$, et al. Assessment of the awareness of COVID-19 among the students enrolled in different medical universities of Pakistan: A cross sectional survey. AL Kindy Coll Med J. 2021;17(1):14-8.

19. Dawood H, Hwayyiz A, Ibrahim I, Abdul Rahman I. The clinical features of COVID 19 in a group of Iraqi patients: A record review. J Fac Med Bagdad 2021;63(1):8-2. 